Jukka Tuomisto, Rainer Aaltonen, Tiina Front, Päivi Mäkinen, Eero Pantzar, Sari Poikela

\title{
KEHITTÄVÄ KOKONAISARVIOINTI MONIMUOTO-OPETUKSESSA
}

\section{Aikuiskasvatuksen cl-opintoja avoimessa yliopistossa}

\section{Monimuoto-opetus on osoittautunut sopivaksi menetelmien yhdistel- mäksi avoimessa korkeakouluopiskelussa. Erityisen hyvin se soveltuu aikuisopiskelijoille, jotka haluavat jatkaa aiempia opintojaan mahdollisimman joustavalla tavalla. Onkin toivottavaa, että "avoimen" kokeilut ovat huomenna arkipäivää kaikkien yliopistoissa opiskelevien keskuudessa.}

Kun "avointa korkeakoulua" alettiin suunnitella maahamme 1970-luvulla, lähtökohtana oli edistää sivistyksellistä tasa-arvoa. Opinnot nähtiin useimmiten aikuisten omaehtoisena väylänä kehittää itseään. Tuolloin luonnollisena tasona pidettiin approbatur-opintoja. Yliopistojen aikuiskoulutustoiminta laajeni voimakkaasti niin meillä kuin muuallakin maailmassa 1980 luvulla. Syynä olivat ensisijaisesti työelämän nopeasta muutoksesta aiheutuvat ammatillisen lisäkoulutuksen tarpeet.

Vaikka osa yliopistojen henkilökunnasta on vanhastaan vierastanut yliopistojen aikuiskoulutusta, erityisesti avoimen yliopiston (arvosanaopetus) toimintaa, tuskin kukaan enää uskoo, että sitä voi tai kannattaa lopettaa. Asialla on selvästi myös positiiviset puolensa. Monet arvosanaopiskelijat ovat saaneet opiskelustaan eväitä sekä ammattiinsa että elämäänsä yleensä. Yliopistoille opetus on tarjonnut kaivatun yhteyden muuhun yhteiskuntaan ja käytännön työelämään. Avoimen yliopiston opettajat ovat saaneet usein aikuisten opettamisesta virikkeitä myös muuhun opetukseensa.
Nykyisin avoimen yliopiston opetus toimii eräänlaisen koelaboratoriona, jossa aktiivisimmat yliopiston opettajat voivat kokeilla ja kehittää uusia opetusmenetelmiä.

Opetuksen taso on nykyisin yhä useammin cumu- tai jopa laudatur -tasoista. Tämä onkin luonnollista, sillä työssä toimivien aikuisten keskuudessa on yhä enemmän sellaisia, jotka ovat suorittaneet jonkun akateemisen arvosanan/tutkinnon yliopistossa ja/tai ovat opiskelleet arvosanoja avoimessa yliopistossa. On luonnollista, että heille tarjotaan mahdollisuus opintojensa jatkamiseen mahdollisimman joustavasti. Monimuoto-opetus on osoittautunut sopivaksi keinoksi, varsinkin kun nykytekniikka on voitu ottaa opetuksessa avuksi. Aivan ongelmitta tämä ei vielä suju, mutta kehityssuunta on selvä. Toivottavaa on, että "avoimen" kokeilut ovat huomenna arkipäivää kaikkien yliopistoissa opiskelevien keskuudessa.

\section{OPINTOJEN TAUSTAA}

Tampereen yliopiston täydennyskoulutuskeskus 
(TYT) ja kasvatustieteiden laitos ovat yhteistyössä järjestäneet aikuiskasvatuksen monimuotoaineopintoja (cl-opinnot) vuodesta 1993 alkaen. Tähän mennessä mukana on ollut yhteensä noin 250 opiskelijaa. Opetus on tarkoitettu lähinnä aikuiskoulutustehtävissä toimiville opettajille, kouluttajille ja suunnittelijoille, joilla on approbatur-arvosanan lisäksi ainakin jonkin verran työkokemusta alalta. Erilaisissa aikuiskoulutustehtävissä toimivia henkilöitä löytyy nykyisin useilta ammattialoilta; teollisuudesta terveydenhuoltoon ja taidealoihin saakka. Eri alojen ammattilaiset saattavat jossakin työuransa vaiheessa päätyä sellaisiin tehtäviin, joihin sisältyy paljonkin koulutustehtäviä, jolloin lisäkoulutus on tarpeen. Opintojen monimuotoinen toteutustapa mahdollistaa osallistumisen kaukana yliopistopaikkakunnilta sekä sellaisilla yliopisto-paikkakunnilla, jossa tämän alan opetusta ei omassa yliopistossa ole saatavilla.

Opinnot koostuvat kahdeksasta opintojaksosta, joiden kokonaislaajuus on vaihdellut 23:sta 20 opintoviikkoon. Opintoihin on sisältynyt seuraavia aihealueita: aikuiskasvatuksen kehitystä ammattialana, aikuisdidaktiikkaa, aikuiskoulutuksen ja työelämän suhteita, kulttuurija vapaa-aikasuuntautunutta aikuiskasvatusta sekä elämänkaarta ja oppimista. Lisäksi opintoihin kuuluivat tutkimusmenetelmäopinnot ja proseminaari. Opintomuotoina ovat vaihdelleet lähi- ja etäopetus (audio/videovälitteisesti) sekä paikallinen opintopiirityöskentely ja itsenäinen opiskelu.

Monimuoto-opintojen käytännön organisoinnista on vastannut TYT yhteistyössä paikallisten opinto-organisaatioiden kanssa. Kasvatustieteiden tiedekunta on hyväksynyt opetussuunnitelman ja sisältösuunnittelun; toteutukseen ovat osallistuneet laitoksen opettajat TYT:n opettajien kanssa. Opiskelijoista suurin osa on pitkään opetustehtävissä toimineita käytännön ammattilaisia, joilla on selvät ammatilliset kehittymistavoitteet. Vuonna 1994 alkaneissa ryhmissä oli mukana useita ammattikorkeakoulun opettajia, jotka sisällyttivät opintonsa uusien pätevyysvaatimusten mukaiseen korkeakoulututkintoon.
Opiskelijoiden ammattitaustat olivat vaihtelevat. Mukana oli niin yksityisyrittäjiä, terveydenhuoltoalan työntekijöitä, ammatillisten oppilaitosten ja kansalais- ja työväenopistojen opettajia kuin yritysten henkilöstö- ja asiakaskouluttajiakin. Päätoimisissa opetustehtävissä toimivia oli noin 50 prosenttia opiskelijoista. Koulutuksen suunnittelu- ja/tai hallintotehtävissä toimi 15 prosenttia. Loput jakaantuivat monelle eri ammattialalle.

Ylivoimainen enemmistö ilmoitti opintojensa aloittamisen syyksi kehittymisen omassa ammatissaan tai suuntautumisen kohti aikuiskoulutusammattia. He kokivat tarvitsevansa työssään enemmän tietoa aikuisten oppimisesta ja teoreettista taustaa aikuiskoulutuksen suunnitteluun. Ajantasalla pysymisellä haluttiin varmistaa oma työpaikka ja vaikuttaa uralla etenemiseen tulevaisuudessa. Ammatillisen kiinnostuksen rinnalla mainitsi moni myös henkilökohtaisen kiinnostuksen aikuiskasvatukseen. Joidenkin perusteluista oli myös nähtävissä selvästi, että opiskelusta oli tullut elämäntapa.

\section{ARVIOINTIMENETELMÄT JA KOHTEET}

Arviointi on vuorovaikutusprosessi, missä opetuksen järjestäjät, vastuuopettajat, tutorit ja opiskelijat arvioivat yhdessä opetuksen järjestelyjen onnistumista, opetuksen kehittämismahdollisuuksia, oppimisen edistymistä ja opetettavien asioiden relevanttisuutta käytännön kannalta. Arviointimenetelmiä ja niiden tehtäviä on tarkasteltu usein kolmella tasolla: määrällisenä, laadullisena ja kehittävänä arviointina (ks. Hakkarainen 1991, 2).

Määrällisessä arvioinnissa kiinnitetään yleensä huomiota vain oppimisen lopputulokseen, joka ilmaistaan määrällisenä suureena. Vaihtoehtona perinteiselle määrälliselle mittaamiselle on kehitelty erilaisia laadullisia menettelytapoja, joille on ominaista subjektiivisen näkökulman tuominen arviointiin. Laadullisessa arvioinnissa tarkastelun kohteena ovat ensisijaisesti oppimisprosessi tai oppimaan oppimisval- 
miuksien kehittyminen. Tätä varten on kehitelty menetelmiä, joiden avulla hankitaan tietoa esimerkiksi opiskelijan oppimisprosessista, ajattelusta, opiskelun motiiveista jne. Näillä menetelmillä pyritään avaamaan opiskelijan näkökulma opetus- ja oppimistilanteisiin.

Määrällinen ja laadullinen arviointi eivät ole kuitenkaan aina kovin kaukana toisistaan. Samoista opiskelijoiden suorituksista voidaan hakea viitteitä edeltävästä oppimisprosessista tai oppimistuloksia voidaan arvioida määrällisesti. Usein määrällinen ja laadullinen arviointi täydentävät toisiaan. Näyttää siltä, että määrällinen ja laadullinen arviointi ovat useimmiten toteavan arvioinnin palveluksessa. Tämä riippuu kuitenkin siitä, annetaanko arvioinnille toteavia vai kehittäviä merkityksiä. (emt. 28.)

Kun arviointia pyritään käyttämään tietoisesti kehittämisen lähtökohtana, kysymys on kehittävästä arvioinnista. Ero toteavan ja kehittävän arvioinnin välillä on keskeinen ja merkittävä. Kehittävä arviointi on samanaikaisesti arviointia ja kehittämistä, se kohdistuu "lähikehityksen vyöhykkeellä“ olevien toimintapotentiaalien kartoittamiseen ja käyttöönottoon. Tästä syystä sen kiinnostuksen kohde on aivan toinen kuin toteavan arvioinnin. Kehitysvaikutuksia ja mahdollisuuksia joudutaan tarkastelemaan laajempina kokonaisuuksina kuin vain erillisinä tietoina ja taitoina. Oppimista tarkastellaan toimintana, joka on olemukseltaan sosiaalinen ilmiö. Tämä tarjoaa mahdollisuuden analysoida opetusta/oppimista kahdella tasolla: 1) oppimista opetustilanteessa toimintana ja 2) oppimisen kehitysvaikutuksia muuhun toimintaan (esimerkiksi työhön). Viimeksimainittu taso edellyttää arvioinnin ulottamista opetustoiminnan ulkopuolelle varsinaiseen käytännön toimintaan. Tällainen arviointi edellyttää useimmiten pitempiaikaista tutkimusta.(emt. 8-12.)

Olemme ottaneet tämän projektin yhteydessä käyttöön käsitteen kehittävä kokonaisarvioin$t i$, jolla tarkoitamme suunnitelmallista koko opetus-, oppimis- ja opiskeluprosessiin kohdis- tuvaa mahdollisimman monipuolista jatkuvaa arviointia, jossa arvioita kerätään niin opiskelijoilta ja tutoreilta kuin opettajiltakin. Kehittävää arviointi on siinä mielessä, että sen tarkoituksena on antaa koulutuksen järjestäjille ja opettajille tietoa opiskelijoiden käytännön tarpeista sekä oppimisesta ja siihen liittyvistä ongelmista. Tietoja voidaan käyttää opetussisältöjen ja -menetelmien jatkuvaan kehittämiseen. Avoin kehityskeskustelu edistää myös opiskelijoiden kriittisyyttä ja reflektiivisyyttä.

Aikuiskasvatuksen aineopintojen yhteydessä on kerätty ja saatu palautetta paljon ja monipuolisesti. Opetusta järjestäneille on välittynyt selkeä kuva monimuoto-opintojen vahvuuksista ja ongelmista. Arviointia on suoritettu sekä opintojaksokohtaisesti että vuosi- ja loppuarviointina.

\section{ARVIOINNIN TULOKSET}

Arvioinneissa on saatu runsaasti kehittämisessä hyödyllistä palautetta. Parannusehdotukset on pyritty ottamaan mahdollisimman nopeasti opetuksessa huomioon. Erityiskiitosta on tullut joustavasta opintomahdollisuudesta opiskella näitä opintoja myös makunnissa. Arvioinnin tuloksia ja saatuja kokemuksia esitellään seuraavassa eräiden keskeisten asioiden osalta tarkemmin.

\section{Audio-opetus}

Alkuvaiheessa audio-opetuksen merkitystä vuorovaikutuksen lisäämisessä selvästi yliarvioitiin. Varsinkin opetuksen alussa usein toistuneet tekniset ongelmat lisäsivät opiskelijoiden kritiikkiä. Pian huomattiin, ettei audio-opetus ollut vuorovaikutuksen ja opiskelun mielekkyyden kannalta kovin antoisaa. Opiskelijat toivoivat enemmän lähiopetusta ja ainakin saavansa audiotilaisuuksien materiaalin etukäteen (tämä asia korjattiinkin toiselle opintoryhmälle). Jotkut toivoivat myös lisää audio-opetusta ja etenkin nauhoitettujen luentojen lainaamista pidettiin hyvänä.

Audio-opetuksen ajoitusta ja merkitystä kan- 


\section{Kuvio 1. Arviointijärjestelmän rakenne}

\begin{tabular}{|c|c|c|c|}
\hline Kuka? & Mitä? & Miten? & Milloin? \\
\hline TYT/suunnittelija, tutor & Järjestelyt & $\begin{array}{l}\text { Kirjalliset kyselyt } \\
\text { Välitön suullinen } \\
\text { palaute }\end{array}$ & Koko opintojen ajan \\
\hline $\begin{array}{l}\text { Opettaja } \\
\text { Opintopiiri/opiskelijat } \\
\text { Työryhmä }\end{array}$ & $\begin{array}{l}\text { Opintojaksot } \\
\text { Oppimisen } \\
\text { prosessi }\end{array}$ & $\begin{array}{l}\text { Suullinen keskustelu } \\
\text { Kirjallinen kysely } \\
\text { Oppimispäiväkirjat } \\
\text { (itselle/opettajalle) } \\
\text { Etätehtävien/kuulus- } \\
\text { telujen/ kirjallisten } \\
\text { töiden arviointi }\end{array}$ & Koko opintojen ajan \\
\hline $\begin{array}{l}\text { TYT/suunnittelija } \\
\text { Työryhmä }\end{array}$ & Vuosiarviointi & Kirjallinen kysely & $\begin{array}{l}\text { Koko opintokoko- } \\
\text { naisuuden päätteeks }\end{array}$ \\
\hline $\begin{array}{l}\text { TYT/ suunnittelija } \\
\text { Työryhmä }\end{array}$ & Loppuarviointi & $\begin{array}{l}\text { Kirjallinen kysely } \\
\text { (tutorit kommento- } \\
\text { vat oman ryhmänsä } \\
\text { palautteen) }\end{array}$ & $\begin{array}{l}\text { Koko opintokokonai } \\
\text { suuden päätteeksi }\end{array}$ \\
\hline $\begin{array}{l}\text { Opiskelija } \\
\text { Työnantaja } \\
\text { Korkeakoulu }\end{array}$ & $\begin{array}{l}\text { Käytännön } \\
\text { toiminta }\end{array}$ & $\begin{array}{l}\text { Itsearviointi \& kes- } \\
\text { kustelu } \\
\text { Tutkimus }\end{array}$ & $\begin{array}{l}\text { Koko ajan käytännör } \\
\text { toiminnassa } \\
\text { Noin } 1 / 2 \text { vuoden } \\
\text { päästä }\end{array}$ \\
\hline
\end{tabular}

nattaa harkita tarkasti, johdattelevana aloitusluentona audio-opetus ei toiminut tyydyttävällä tavalla.

Saadut kokemukset ovat selvästi samansuuntaisia kuin Viitalan ja Iso-Nikkilän artikkelissa mainitut toisaalla tässä lehdessä.

\section{Opintoaineistot}

Opiskelijat saivat opintoihin liittyen kansioon kootut opintojaksokohtaiset artikkelikokoelmat sekä yleiset ja jaksokohtaiset ohjeet ja tehtävät. Artikkelit olivat peräisin pääosin kasvatusalan lehdistä, ulkomaisista tieteellisistä aikakausjulkaisuista ja monografioista. Artikkelit edustivat läpileikkausta tieteellisestä kirjoittelusta, eivät pelkästään uusinta ja ajankohtaisinta tietoa, mitä osa opiskelijoista kritisoi.
Tarkoituksena ei kuitenkaan ollut vain välittää uusimpia trendejä, vaan antaa tietoa myös taustoista ja historiallisista kehitysvaiheista. Vasta niiden pohjalta voidaan arvioida, mikä on todella uutta ja uudistavaa. Opiskelijat pitivät artikkelikokoelmia erittäin käyttökelpoisina ja hyvätasoisina myös myöhempää käyttöä ja käytäntöä ajatellen. Vuosi- ja loppuarvioinneissa saatujen palautteiden perusteella monien opiskelijoiden mielestä kootut artikkelikokoelmat olivat parasta koko opinnoissa.

\section{Tutorointi ja opintopiirit}

Tutoreilta edellytettiin korkeakoulutututkintoa aikuiskasvatuksesta, kokemusta aikuiskoulutustehtävistä sekä kiinnostusta ja valmiuksia ryhmänohjaukseen. Tutorit perehdytettiin tehtäviinsä tutorkoulutuspäivillä. Näissä tilaisuuk- 
sissa käytiin kokonaisuudesta vastaavien opettajien ja suunnittelijan kanssa läpi monimuotoopiskelun sisältöjä ja työtapoja. Lisäksi järjestettiin puhelinneuvotteluja tutoreiden, opettajien ja TYT:n välillä.

Keskeisellä sijalla opinnoissa olivat paikalliset tutoreiden vetämät opintopiirit. Tutorien tehtäviin kuului järjestää opintopiiritoiminnan lisäksi henkilökohtainen opinto-ohjaus vastaanotto- tai muina sovittuina aikoina, osallistua audio-opetustilanteisiin ryhmänsä puheenjohtajana ja osallistua yliopisto-opettajan pitämiin lähiopetusjaksoihin (osallistumista suositeltiin). Palautelomakkeista ilmenee, että opintopiirit herättivät kannanottoja laidasta laitaan. Osan mielestä opintopiirit olivat melkeinpä opintojen parasta antia, erään opiskelijan sanoin: "Kun useampi ammatti-ihminen työskentelee yhdessä, avartuu omakin ymmärtämys aivan uudella tavalla”. Kriittisesti opintopiirityöskentelyyn suhtautuvat olivat pettyneitä tehottomaan ajan käyttöön ja sosiaalisen funktion korostumiseen sisällöllisen annin kustannuksella.

Pantzarin (1995) tutkimus vahvistaa käsityksen tutorjohtoisten opintopiirien luonteesta. Yli 40 prosenttia osallistuneista ilmoitti olevansa mukana ensisijaisesti sosiaalisen kanssakäymisen vuoksi. Vain noin 10 prosenttia piti opintopiirejä ensisijaisesti opinnollisina. Tuloksia arvioitaessa on kuitenkin muistettava, että merkittävä osa opiskelijoista näkee ryhmän toiminnan sekä opinnollisena että sosiaalisena tapahtumana.

Tutoreiden persoonalliset eroavuudet olivat tietenkin suuria, mutta samastakin opintopiiriryhmästä annettiin palautetta puolesta ja vastaan. Opiskelijoiden odotukset ohjattua ryhmätyöskentelyä kohtaan olivat suuret ja jos ne eivät täyttyneet, olivat pettymyksetkin suuria. Pantzarin (1995) tutkimuksesta ilmenee, että 1/3 opiskelijoista koki tutorin toiminnan vastanneen omia odotuksia. Tutortoiminta ei vastannut odotuksia noin 1/3:n mielestä.

Useissa palautelomakkeissa toivottiin tutorilta jämäkämpää otetta. Yhden tutorin vastakom- mentti tähän: "Tietoisesti pyrin kuitenkin siihen, etten perinteisen opettajan mukaisesti toimisi auktoriteettina ja katederiluennoijana/käskijänä”. Tutor oli myös keskustellut roolistaan opiskelijaryhmän kanssa. Etenkin yhteisten kokoontumisaikojen sopiminen koettiin toisinaan todella vaikeaksi. Joidenkin opiskelijoiden oma iltaopetus haittasi aikojen sopimista ja kun enemmistö ryhmäläisistä joutui matkustamaan vähintään $90 \mathrm{~km}$, on ymmärrettävää, että päätöksenteko oli monimutkaista ja välillä tuskallistakin tässä ryhmässä. Yleisvaikutelmaksi jäi, että tutorin rooli olisi vaatinut vieläkin tarkempaa selkeyttämistä sekä järjestäjien taholta että tutorin taholta yhdessä ryhmän kanssa alusta lähtien.

Aikuisopiskelijat eivät ole aina niin itseohjautuvia, että tutorin rooli itseohjautuvien opiskelijoiden ohjaajana voisi toteutua. Keskeinen kysymys on, miten tutor voi kannustaa vähemmän itsenäisiä opiskelijoita itseohjautuvampaan toimintaan ja miten tutoroida jo pitemmälle itsenäistyneitä oppijoita.

Pantzarin (1995) tutkimuksen mukaan tutorin vetämiin opintopiireihin ilmoitti osallistuneensa aktiivisesti 62 prosenttia opiskelijoista. Naiset olivat miehiä aktiivisempia osallistujia. Osallistumisen esteitä olivat tavallisesti pitkät matkat, ajanpuute ja se, että ryhmät eivät vastanneet odotuksia.

\section{Omaehtoiset opintoryhmät}

Opiskelijoita kannustettiin omaehtoisten opintoryhmien perustamiseen ja muutamissa opintopiireissä niitä muodostettiinkin. Opintoryhmät saattoivat kokoontua omalla ajallaan annettuja teematehtäviä työstäen ja olla yhteydessä tutoriin sovitulla tavalla. Opintoryhmien toimintaa oli helppo muokata osallistujien toiveiden mukaiseksi ja opiskelijat olivat niiden toimintaan hyvin tyytyväisiä. Pantzarin tutkimuksen mukaan näihin itsekoottuihin ryhmiin osallistui peräti 54 prosenttia 1993 aloittaneista opiskelijoista. Erityisesti opiskelupaikkakunnalta kaukana asuvat (67\% näistä) muodostivat maantieteellisiä etäryhmiä. Sosiaalinen funktio 
ei näillä etäryhmillä ollut keskeinen, vaan 52 prosenttia näki ryhmän merkityksen ensisijaisesti opinnollisena. Mielenkiintoista oli se, että avoimen yliopiston opiskelukokemusta omaavat opiskelijat olivat aktiivisempia (62\%) kuin ensikertalaiset $(33 \%)$ muodostamaan näitä opintoryhmiä.

\section{Kirjalliset tehtävät}

Etätehtävien tavoitteena on nostaa opintojakson keskeinen sisältö pohdinnan ja sovelluksen kohteeksi. Lähteinä käytetään jakson opetussuunnitelmassa mainittua kirjallisuutta sekä artikkelimateriaalia. Myös muun materiaalin käyttöä suositellaan. Opiskelijat pitivät etätehtäviä hyvin laadittuina ja mielekkäinä aikuisopiskelijoille. Käytännön ja teorian yhdistyminen oli monen mielestä etätehtävien työstämisen parasta antia.

Opettajan näkökulmasta etätehtävät antoivat opiskelijalle mahdollisuuden pitkäjännitteiseen ja syvälliseen tiedon prosessointiin. Edellyttihän tehtävien hyväksyttävä tekeminen kirjallisuuden lukemisen lisäksi luetun (ja omien aikaisempien kokemusten ja näkemysten) kriittistä prosessointia ja analysointia. Tehtävät olivat essee-tyyppisiä, joten arvioinnissa painottuivat nimenomaan kirjoittajan oma kädenjälki ja ajatuksenjuoksu, sikäli kuin ne olivat sisällön suhteen relevantteja ja hyvin perusteltuja. Arviointitavalla (hyväksytty/hylätty) saattoi olla merkitystä joidenkin opiskelijoiden itselleen asettamille tavoitteille eikä etätehtäviin haluttu panostaa kovin paljon aikaa ja työtä. Etätehtävien numeroarviointi nähtiin kuitenkin opettajien mielestä ongelmallisena ja kirjallista palautetta pidettiin riittävänä.

Etätehtävien arvioinnin prosessi oli tietyllä tavalla "henkilökohtaisempi" kuin esimerkiksi tenttivastausten. Opiskelijat käsittelivät tehtäviä eri näkökulmista, painottivat eri asioita, vetivät samoista lähteistä erilaisia johtopäätöksiä jne. "Oikeita" vastauksia ei sinänsä ollut, vaan arvioinnissa huomio kiinnittyi enemmänkin tehtävien kokonaisvaltaiseen käsittelyyn; tehtävän ymmärtämiseen, ja kirjallisten lähteit- ten käyttöön, omien kokemusten ym. materiaalien välityksellä hankitun tiedon analysointiin ja tulkintaan. Parhaimmat vastaukset olivat hyvin laaja-alaisia ja korkealle abstraktiotasolle yltäviä esseitä, valtaosan jäädessä kuitenkin enemmän toistavalle, referaattimaiselle tasolle.

Arvioinnin kohteena oli valmis "lopputuote", eli se oli luonteeltaan summatiivista. Itse oppimisen prosessiin ja sen ohjaamiseen ei etätehtävien osalta pystytty vaikuttamaan. Toisaalta ne oli tarkoitettukin yksilöllisesti toteutetuiksi opintojen osiksi. Didaktiikan harjoitus- ja proseminaarityön ohjaaminen antoi enemmän mahdollisuuksia reflektointiin ja työn prosessinomaiseen kehittämiseen. Kirjallinen palaute pyrki osaltaan edistämään myös oppimisen taitoja; osoittamaan hyviä ja kehittämistä edellyttäviä puolia. Käytännössä tämä oli kuitenkin vaikeaa, koska kaikki vastaukset eivät antaneet mitään vihjeitä oppijan omista ajatuksista tai toimintatavoista - oli vaikea päätellä, miten kirjoittaja oli päätynyt kirjoittamaansa vastaukseen. Parempaan oppimiseen ohjaamisen tavoite tietenkin tällöin kärsi.

Kaiken kaikkiaan opettajille jäi sellainen mielikuva, että etätehtävät otettiin tosissaan ja niitä pidettiin mielekkäinä. Tietynlainen ristiriita jäi kuitenkin näiden tehtävien oppimisprosessiin liittyvän merkityksen ja opintojen kokonaisarvioinnin suhteen. Ihmiselle on ominaista pyrkimys toimia "minimiponnistuksen" periaatteella, ja uuden oppiminen edellyttää usein paljon työtä. Ilman tavoitetta ja motivaatiota oppimisen tarvitsemia ponnistuksia ei jakseta ylläpitää. Onko arvioinnin muuttaminen numeeriseksi kuitenkaan ratkaisu tässä tapauksessa? Tarkoitus ei ole ollut saada opiskelijaa panostamaan resurssejaan mihinkään vähemmän tärkeään, vaan antaa hänelle mahdollisuus syvälliseen oppimiseen.

\section{Proseminaari}

Proseminaarityöskentelyssä toteutettiin prosessikirjoittamisen ideaa, jossa arviointi kohdistuu myös työskentelyn eri vaiheisiin, ei ainoas- 
taan lopputulokseen. Seminaarityöskentelyn lopuksi opiskelijat arvioivat lisäksi 2-3 hengen pienryhmissä tai yksin omaa kirjoittamisprosessiaan, ohjausta sekä opintopiirien että seminaariviikonlopun työskentelyä.

Ohjausta arvioitaessa koettiin, että dialogi ohjaajan kanssa toimi hyvin. Tarvittaessa oli mahdollista tarkistaa työn suuntaa. Ylipäätään ohjauksen määrä nähtiin riittävänä. Etuna koettiin se, että ohjaus oli joustavaa sekä ajallisesti että muodoiltaan. Mahdollisuutta puhelinohjaukseen pidettiin hyvänä erityisesti alkuvaiheessa. Toisaalta se sai osakseen samoja kommentteja kuin audio-opetus: vuorovaikutuksen luonne kärsi helposti. Tampereen ulkopuolisten ryhmien osalta kontaktiohjaukseen ei ollut mahdollisuutta, vaan ohjauskeskustelut käytiin puhelimessa, sähkopostitse tai kirjeitse.

Seminaaritöiden käsittelyä varten oli varattu yksi viikonloppu kullakin paikkakunnalla. Tämä koettiin antoisana, mutta raskaana, esimerkiksi ajankäyttö oli hyvin tiivistä. Osa toivoikin töiden käsittelyä pienemmissä 5-6 hengen ryhmissä, jolloin yhteiselle keskustelulle ja ohjaajan kommenteille olisi jäänyt enemmän aikaa. Työt käsiteltiin konferenssimuotoisesti, jolloin tekijät esittelivät työnsä lyhyesti ja muu ryhmä tutustui töihin etukäteen tiivistelmien pohjalta, lisäksi käytettiin perinteistä opponointia. Sen etuna nähtiin mahdollisuus moneen erityyppiseen työhön tutustumiseen tiiviissä aikataulussa. Ilmapiiri koettiin avoimena ja innostavana. Pääosin opiskelijat olivat tyytyväisiä saamaansa ohjaukseen kaikissa ryhmissä ja olivat lähinnä pahoillaan siitä, etteivät olleet ehtineet tai osanneet hyödyntää sitä enemmän. Seminaaritöiden käsittelyä konferenssimuotoisesti yhden intensiivisen viikonlopun aikana pidettiin jopa opiskelun huipennuksena.

\section{Kirjatentit}

Opetusohjelmassa olevien kirjallisuusosien yleisenä tarkoituksena on täydentää ja syventää perusasioiden käsittelyä sekä tarjota uutta tietoainesta. Tarkoituksena on myös kehittää opiskelijan itsenäisiä tiedonomaksumisvalmiuksia: kykyä löytää, tiivistää ja omaksua suurehkosta tekstimäärästä olennaiset asiat ja välittää ne ymmärrettävästi ja hyvällä tyylillä lukijalle. Tärkeä tavoite on myös alan ammattiteksteihin liittyvä kielitaidon kehittäminen, mikä myöhemmin työelämässä on keskeinen edellytys alan vieraskielisen kirjallisuuden itsenäiselle seuraamiselle.

Käytännössä kirjatentit ovat osoittautuneet aineopintokokonaisuuden työläimmäksi ja karsivimmaksi osaksi. Useimmat opiskelijat ovat jättäneet kirjatentin viimeiseksi suoritukseksi. Hylättyjä on ollut suhteellisen runsaasti jokaisessa tentissä. Joidenkin opiskelijoiden selvästi puutteellinen kielitaito on ollut vaikeuksien yksi keskeinen syy, näin siitä huolimatta, että opiskelijoiden kielitaito pyrittiin varmistamaan valinnan yhteydessä. Nyt mukana on ollut sekä todella hyvän kielitaidon omaavia että joitakin, joilla se ei ole ollut kovin hyvä. Myöhemmissä valinnoissa tasovaatimusta on tiukennettu. Toisaalta on todettava, että kieliongelmat ovat varsinaisten yliopisto-opiskelijoidenkin keskuudessa edelleen yllättävän suuria. Ongelmia on myös kirjojen ydinasioiden, tärkeiden käsitteiden, teorioiden, erottelujen ja kirjan kirjoittajien omien kontribuutioiden tunnistamisessa ja omaksumisessa. Aikaisemmista koulutus- ja oppimiskokemuksista saadut valmiudet vaihtelevat suuresti.

Varsinaisia kirjatenttejä opintoihin kuului 1-2 riippuen opintojen aloitusajankohdasta. Monet opiskelijat pitivat tenttimistä vanhanaikaisena ja monimuoto-opiskeluun huonosti sopivana. Vaihtoehtoisiksi suoritustavoiksi ehdotettiin ryhmätenttimistä, esseetehtäviä ja referaatteja. Yksi opintoryhmä laati kirjelmänkin tämän asian puolesta. Koska suurin osa suorituksista jo perustui itsenäisiin kirjallisiin töihin, ei tenttimisestä haluttu kuitenkaan kokonaan luopua ja niin yksi kirjatentti on jäljellä edelleenkin. Opintojen ohjaustyöryhmässä on keskusteltu vilkkaasti erilaisista vaihtoehdoista, mutta ei ole ainakaan toistaiseksi katsottu aiheelliseksi luopua kokonaan kirjatentistä. 


\section{OPETUKSEN KEHITTÄMINEN JA LAADUN VARMISTAMINEN TULEVAISUUDESSA}

On selvää, että monimuoto-opiskelun merkitys kasvaa kaikessa aikuisopiskelussa. Perusteluina usein esitettyjen kustannustehokkuuden ja kehittyvien itseopiskeluvalmiuksien lisäksi voidaan mainita konstruktivistisen oppimisnäkemyksen korostaminen ja joustavien oppimisympäristöjen luominen.

Opetusteknologiset ratkaisut kehittyvät nopeasti, mutta audio/ videoetäopetus ei voi koskaan täysin korvata persoonallista kontaktia ohjaajan ja oppijoiden välillä. Videoneuvottelulaitteistojen leviäminen on tehnyt mahdolliseksi audio-opetuksen muuttamisen videovälitteiseksi, jolloin liikkuva kuva on lisännyt läheisyyden tunnetta. Datansiirto nykyisellä linjakapasiteetilla tuottaa kuitenkin vielä ongelmia kuvan laadussa ja järjestelmän ohjauksessa. Etäopetuksen funktiota opintojen kokonaisuudessa kannattaa myös tarkoin harkita.

Opintojen arvioinnin tulee perustua viimekädessä opetukselle asetettuihin tavoitteisiin. Avoimissa yliopisto-opinnoissa tavoitteet ovat samat kuin tiedekunnissakin, mutta painotukset voivat vaihdella. Tiedekunnassa opintojen painopiste on ainakin toistaiseksi ollut tieteellisten tutkijavalmiuksien kehittäminen, päämääränä erityisesti lopputyö, pro gradu. Myös avoimessa yliopistossa pyritään edistämään opiskelijoiden tieteellisiä valmiuksia ja heiltä vaaditaan aivan samat menetelmäopinnot kuin muiltakin opiskelijoilta, mutta opintojen painopiste on kuitenkin enemmän teorian ja käytännön integroimisessa, missä voidaan käyttää hyväksi opiskelijoiden aikaisempaa elämän- ja työkokemusta.

Projektin yhtenä tavoitteena on ollut, että monimuoto-opetuksesta saatuja kokemuksia voidaan hyödyntää myös yliopiston perusopetuksessa. Tulevaisuudessa myös yliopiston "varsinaisille" opiskelijoille tultaneen tarjoamaan monimuoto-opintoja perinteisen opetuksen rin- nalla. Näin voidaan lisätä valinnanvaraa ja parantaa yksilöllisen suunnittelun mahdollisuuksia yliopisto-opiskelussa.

Saamamme kokemukset herättävät myös miettimään monien erillisten opintojärjestelmien tarpeellisuutta. Nykyisessä mallissa avoimilla yliopistoilla, kesäyliopistoilla, ammatillisella täydennyskoulutuksella ja vapaan sivistystyön organisaatioilla on paljon päällekkäistä opetustarjontaa. Lähtökohtana tulisi olla mahdollisimman joustava palvelu opiskelusta kiinnostuneille aikuisille ja resurssien optimaalinen hyödyntäminen.

Arvioinnilla on keskeinen rooli avoimen yliopisto-opetuksen laadun varmistamisessa. Opetusmuotojen ja opintojen arvioinnin kehittämiseen on panostettu avoimessa yliopistossa monissa tapauksissa huomattavasti enemmän kuin tiedekunnan vastaavassa opetuksessa. Tämäntyyppisistä hankkeista raportoiminen ja avoin keskustelu toivottavasti lopettavat puheet avoimen yliopiston "kakkoslaadusta", josta tämänkin lehden palstoilla on kirjoiteltu (ks. Eskola 1996).

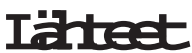

AALTONEN, R., FRONT, T., MÄKINEN, P., PANTZAR, E., POIKELA, S. \& TUOMISTO, J. (1996) Kokonaisvaltainen kebittävä arviointi monimuoto-opetuksessa. Aikuiskasvatuksen monimuotoaineopintojen arviointi. Tampereen yliopiston täydennyskoulutuskeskus, MoNet-monimuoto- ja etäopetus.

ESKOLA, J. (1996) Tutkinto vai sivistys? Avoin yliopisto ja tutkintotavoitteisuus. Aikuiskasvatus 16, 2, 146-150.

HAKKARAINEN, P., WAHLSTRÖM, R. \& VÄLIMAA, J. (toim.). (1991) Korkeakoulutuksen kebittäminen ja laadun arviointi. Kasvatustieteiden tutkimuslaitoksen julkaisusarja B. Teoriaa ja käytäntöä 71. Jyväskylän yliopisto.

PANTZAR, E. (1995) Study Circles - a Critical Phase in Learning at a Distance. In Klasson, M. et al (eds.) Sosial Change and Adult Education Research. Linköping. Pp. 228-239.

Artikkeli saapui 24.1.1997. Se hyväksyttiin julkaistavaksi 3.4.1997. 